\title{
DAMPAK PENINGKATAN USIA HARAPAN HIDUP PENDUDUK INDONESIA TERHADAP STRUKTUR DEMOGRAFI DAN PERAWATAN LANJUT USIA
}

\author{
Oleh \\ Suryadi \\ suryadie.aj@gmail.com
}

\begin{abstract}
ABSTRAK
Perbaikan tingkat kesejahteraan masyarakat dan kemajuan dalam bidang kedokteran telah menjadikan usia harapan hidup penduduk semakin panjang, dampak langsungnya adalah peningkatan jumlah penduduk lanjut usia dan kebutuhan akan pola perawatan lansia. permasalahan semakin kompleks ketika terjadi pergeseran model keluarga dari keluarga luas menjadi keluarga inti. menghadapi tantangan tersebut para peneliti dan penggiat sosial kemasyarakatan harus dapat menemukan alternatif kebijakan yang dapat dilaksanakan pada akar rumput. sehingga konsep lansia tetap aktif dan produktif tetap menjadi keniscayaan untuk dilakukan.

Kata kunci: usia harapan hidup, lansia, aktif dan produktif
\end{abstract}

\begin{abstract}
The improvement in the level of community welfare and advances in the field of medicine has made the increasing of population life expectancy at birth (eo) is longer, the direct impact of that shifting is an increase in the number of elderly people and the need for the elderly care pattern or model. The problem is more critical when there is a shift in the family model from an extended family to a nuclear family. Envisage these challenges, researchers and community social activists must be able to find alternative policies that can be implemented at the grassroots spheres. so that the concept of the elderly remaining active and productive remains a necessity to carried out.

key word: life expectancy, elderly, active and productive
\end{abstract}

\section{Transisi kependudukan}

Penuaan penduduk me-
rupakan ciri demografi abad
milenium. Keadaan ini merupakan
proses transisi demografi, yaitu

fenomena penurunan angka mortalitas seiring dengan semakin rendahnya angka fertilitas. Di samping itu kemajuan di bidang teknologi dan ilmu kedokteran telah 
mampu menekan angka kematian yang disebabkan oleh penyakit menular. Bersamaan itu tingkat pendidikan dan pengetahuan masyarakat yang semakin membaik sehingga meningkatkan usia harapan hidup penduduk (life expectancy at birth) sebagai konsekuensinya. Dampak langsung dari peningkatan usia harapan hidup adalah peningkatan jumlah penduduk lansia (elderly).

Proses penuaan penduduk di Indonesia akan terus terjadi dan menjadi tangtangan tersendiri bagi upaya pemenuhan kesejahteraan penduduk lanjut lansia. Keadaan ini terjadi sebagai konsekuensi keberhasilan program $\mathrm{KB}$ menekan angka fertilitas, terlepas metode sosialisasinya kepada masyarakat yang sarat akan nuansa pressure dari penguasa waktu itu dengan dalih pembangunan dan target kuantitatif semata. Padahal dampak dari program KB yang bernuansa tekanan dan penurunan angka semata telah mengakibatkan lahirnya diskriminasi dan pelecehan perempuan dalam memperoleh pelayanan reproduksi sehat dan manusiawi. Karena semua institusi yang relevan, baik pemerintah atau non pemerintah memiliki tanggungjawab secara bersama-sama untuk memikirkan solusi terbaik baik penanganannya tersebut.
Fenomena sebagaimana disebutkan di atas belum menjadi pertimbangan para pembuat kebijakan, sehingga lumrah saja delegasi Indonesia pada Pertemuan Dunia Tentang Lansia di Wina Austria tahun 1982, masih dapat mengatakan bahwa penuaan penduduk di Indonesia bukan merupakan tekanan masalah yang berarti dibandingkan masalah sosialekonomi lainnya, seperti kemiskinan atau pengangguran. Keyakinan tersebut didasarkan pada jaminan sosial dalam nilai dan budaya yang masih memadai dari keluarga dan masyarakat. Hal tersebut tidaklah berlebihan diutarakan sebagai rasa optimis terhadap pola aliran santunan yang diberikan anak-anak ketika orang tua memasuki masamasa lanjut usia, baik berbentuk bantuan materi, keperawatan atau yang bersifat dukungan moralspiritual. Pernyataan ini juga pada dasarnya sangat sesuai dengan nilai budaya bangsa Indonesia.

Namun demikian kondisi tersebut telah mengalami pergeseran khususnya pada situasi keluarga di kota-kota di Indonesia. Di mana karakteristik kehidupan masyarakat urban lebih kompleks dan multi problems. Kondisi dan situasi psikososial dan ekonomi di dalam kehidupan masyarakat urban menjadikan nilai tradisional dan dukungan terhadap penduduk lansia 
sedikit banyak terlah terganggu. Meskipun secara konseptual traditional value tersebut masih dipegang dalam praktek kehidupan menjadi kian longgar. Demikian juga tipologi nuclear family (keluarga ini) merupakan ciri dari model dan jumlah anggota keluarga ada masyarakat urban. Situasi tersebut akan berakibat pada keberadaan perawat lansia (care giver) dalam keluarga yang semakin berkurang.

Dalam waktu hampir lima dekade, persentase lansia Indonesia meningkat sekitar dua kali lipat (1971-2017), yakni menjadi 8,97 persen $(23,4$ juta) di mana lansia perempuan sekitar satu persen lebih banyak dibandingkan lansia laki-laki (9,47 persen banding 8,48 persen). Selain itu, lansia Indonesia didominasi oleh kelompok umur 60-69 tahun (lansia muda) yang persentasenya mencapai 5,65 persen dari penduduk Indonesia, sisanya diisi oleh kelompok umur 70-79 tahun (lansia madya) dan 80+ (lansia tua). Pada tahun ini sudah ada lima provinsi yang memiliki struktur penduduk tua di mana penduduk lansianya sudah mencapai 10 persen, yaitu: DI Yogyakarta (13,90 persen), Jawa Tengah (12,46 persen), Jawa Timur (12,16 persen), Bali (10,79 persen) dan Sulawesi Barat (10,37 persen) (BPS, 2018).

\section{Tabel}

Perkembangan Penduduk Lansia (60+) Di Indonesia

Tahun 1971 - 2020

\begin{tabular}{ccccccc}
\hline \multirow{2}{*}{ Tahun } & \multicolumn{2}{c}{ Perkotaan } & \multicolumn{2}{c}{ Perdesaan } & \multicolumn{2}{c}{ Kota + Desa } \\
\cline { 2 - 7 } & \multicolumn{1}{c}{ Jmlh } & $\%$ & Jmlh & $\%$ & Jmlh & $\%$ \\
\hline 1971 & 726.633 & 3,73 & 4.544 .241 & 4,64 & 5.306 .874 & 4,48 \\
1980 & 1.452 .934 & 4,42 & 6.545 .609 & 5,75 & 7.998 .543 & 5,45 \\
1985 & 2.196 .271 & 5,26 & 8.361 .286 & 6,75 & 11.277 .557 & 6,29 \\
1990 & 4.209 .999 & 5,88 & 8.568 .213 & 6,96 & 12.778 .212 & 6,56 \\
1995 & 4.027 .515 & 5,76 & 9.271 .073 & 7,43 & 13.298 .588 & 6,83 \\
2000 & 7.793 .880 & 7,60 & 9.973 .829 & 8,29 & 17.767 .709 & 7,97 \\
2005 & 9.572 .274 & 8,22 & 10.364 .621 & 8,74 & 19.936 .895 & 8,48 \\
2010 & 12.380 .321 & 9,58 & 11.612 .232 & 9,97 & 23.992 .553 & 9,77 \\
2020 & 15.714 .952 & 11,20 & 13.107 .927 & 11,51 & 28.822 .879 & 11,34 \\
\hline
\end{tabular}

Sumber: BPS, Laporan Sosial

Indonesia 1997

Faktor lain adalah peningkatan kesadaran masyarakat terhadap penggunaan layanan kesehatan modern dan kemajuan dalam bidang teknologi kedokteran dengan telah ditemukan obat-obatan anti biotik dan imunisasi sehingga dapat mengurangi prevalensi penyakit parasit dan penyakit menular lainnya yang mematikan. Kondisi tersebut memiliki dampak terhadap semakin meningkatnya kualitas hidup masyarakat yang menyebabkan usia harapan hidup waktu lahir penduduk semakin meningkat. Sehingga proses penuaan penduduk merupakan fenomena global yang tidak dapat dihindari, demikian pula Indonesia 
sebagaimana dapat dilihat pada tabel (di atas).

Dalam waktu hampir lima dekade, persentase lansia Indonesia meningkat sekitar dua kali lipat (1971-2017), yakni menjadi 8,97 persen $(23,4$ juta) di mana lansia perempuan sekitar satu persen lebih banyak dibandingkan lansia laki-laki (9,47 persen banding 8,48 persen). Selain itu, lansia Indonesia didominasi oleh kelompok umur 60-69 tahun (lansia muda) yang persentasenya mencapai 5,65 persen dari penduduk Indonesia, sisanya diisi oleh kelompok umur 70-79 tahun (lansia madya) dan 80+ (lansia tua). Pada tahun ini sudah ada lima provinsi yang memiliki struktur penduduk tua di mana penduduk lansianya sudah mencapai 10 persen, yaitu: DI Yogyakarta (13,90 persen), Jawa Tengah (12,46 persen), Jawa Timur (12,16 persen), Bali (10,79 persen) dan Sulawesi Barat (10,37 persen). (BPS, 2017)

Struktur ageing population merupakan cerminan dari semakin meningginya rata-rata Usia Harapan Hidup (UHH) penduduk Indonesia. Tingginya UHH merupakan salah satu indikator keberhasilan pencapaian pembangunan nasional terutama di bidang kesehatan. Sejak tahun 2004 - 2015 memperlihatkan adanya peningkatan Usia Harapan Hidup di Indonesia dari 68,6 tahun menjadi 70,8 tahun dan proyeksi tahun 2030-2035 mencapai 72,2 tahun (lihat Gambar 1 berikut).

\section{Gambar 1}

Usia Harapan Hidup Indonesia Tahun 2008 - 2015

dan Proyeksi Tahun 2030-2035

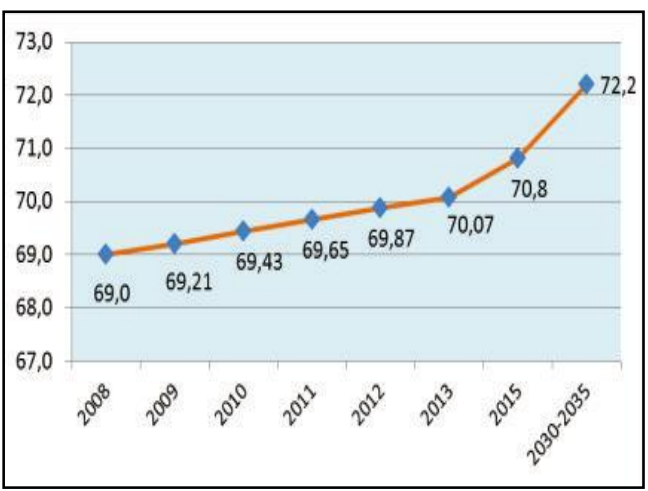

Sumber: Badan Pusat Statistik Rl, 2015

Meningkatnya jumlah lansia pada setiap tahunnya secara otomatis memberikan pengaruh terhadap semakin banyaknya jumlah rumah tangga yang dihuni oleh lansia. Selama empat tahun terakhir, rumah tangga lansia bertambah hampir dua persen (dari 24,5 persen menjadi 26,35 persen), di mana 60 persen di antaranya menjadikan lansia sebagai kepala rumah tangga.

Yang menarik dari keberadaan lansia Indonesia adalah ketersediaan dukungan potensial baik ekonomi maupun sosial yang idealnya disediakan oleh keluarga. Data Susenas 2017 menunjukkan bahwa hampir 10 persen lansia 
tinggal sendiri, di mana lansia perempuan 14,37 persen dan lansia laki-laki 4.75 persen. Dibutuhkan perhatian yang cukup tinggi dari seluruh elemen masyarakat terkait hal ini, karena lansia yang tinggal sendiri membutuhkan dukungan dari lingkungan sekitar mereka mengingat hidup mereka lebih berisiko.

Hasil proyeksi penduduk 2010-2035, Indonesia akan memasuki periode lansia (ageing), dimana $10 \%$ penduduk akan berusia 60 tahun ke atas, di tahun 2020 seperti terlihat pada gambar di bawah. Untuk tahun yang akan datang terdapat kecenderungan jumlah lansia akan semakin banyak di kota, hal ini terkait dengan proses urbanisasi, pergerakan penduduk itu sendiri atau perubahan wilayah yang semula berstatus rural menjadi berkarakter urban. Hal ini tentu akan semakin menarik untuk dikaji lebih mendalam karena ciri penduduk urban yang lebih individualis dan pola keluarga kecil merupakan tren keluarga Indonesia pada masa yang akan datang.

\section{Gambar 2}

Persentase Penduduk Lansia di Indonesia

Tahun $2010-2035$

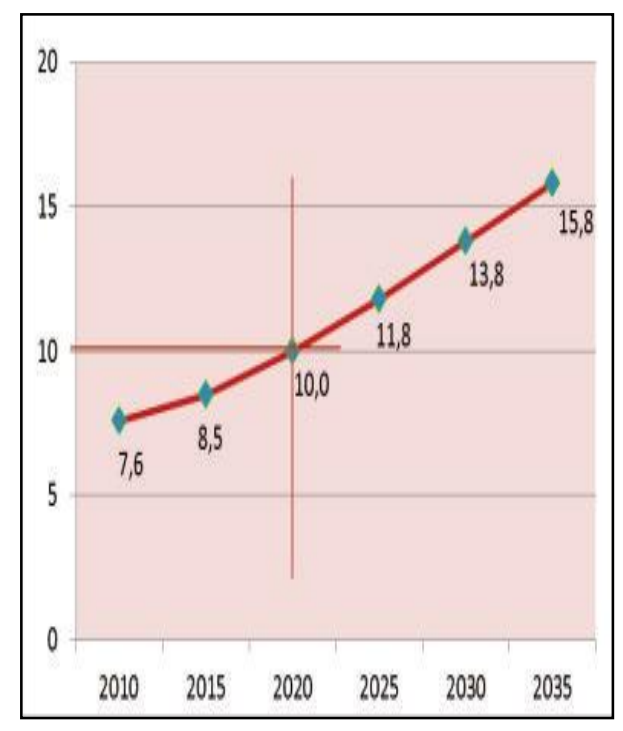

Sumber: Badan Pusat Statistik,

Proyeksi Penduduk 2010-2035

\section{Permasalahan Lansia}

Implikasi peningkatan pada usia harapan hidup penduduk penduduk lansia akan membawa pengaruh dalam semua sektor pembangunan. Perubahan struktur usia penduduk juga berimplikasi pada skala kebijakan pemerintah, tidak hanya pada sektor kependudukan berupa peningkatan jumlah penduduk lansia saja tetapi juga pada sektor lainnya seperti sektor kesehatan, sosial dan ekonomi.

Pertama, aspek sosial, perubahan struktur keluarga dari extended family menjadi nuclear 
family akan berdampak pada keberadaan pemberi perawatan bagi lansia demikian pula dengan semakin meningkatnya jumlah perempuan yang masuk ke sektor publik tentunya semakin mempengaruhi struktur tradisi keluarga dalam memelihara lansia.

Penurunan jumlah keluarga di Indonesia dari rata-rata 5,3 pada tahun 1971 menjadi 4,5 pada tahun 1990. Fenomena tersebut pada dasarnya bukanlah menjadi masalah ketika penurunan itu juga diiringi kualitas anggota keluarga, bukan saja dalam makna materil atau kecerdasan tetapi juga kualitas moral dan emosional yang akan dapat menjalani kehidupan secara proporsional (Djuhari, 1998). Keadaan ini harus dapat diantisipasi dan dicarikan alternatif pemecahan masalahnya. Karena friksi antara kelompok muda dan kelompok tua akan semakin melebar dalam kehidupan di kota-kota besar.

Perubahan pola dan struktur keperawatan kepada lansia akan lebih terasa pada kelompok masyarakat di perkotaan di mana modernisasi telah terjadi. Perubahan dari status pekerjaan pertanian menjadi industri atau jasa yang lebih dominan. Di samping itu turut aktifnya perempuan ke dalam sektor publik merupakan faktor lain, berkurangnya pemberi perawatan kepada lansia (care giver). Sehingga dapat disimpulkan bahwa saat ini dan masa yang akan datang permasalahan keperawatan lansia merupakan tantangan yang serius mengingat jumlah lansia yang terus meningkat. Pada saat yang bersamaan banyak hasil penelitian menunjukkan masih tingginya angka kesakitan dan disabilitas yang dialami oleh lansia kita.

Ada 2 antisipasi program yang harus dilaksanakan oleh instansi dan lembaga terkait berkenaan dengan fenomena tersebut:

1. Pembenahan kembali struktur budaya dalam keluarga untuk menopang sistem jaminan kepada lansia, dalam kultur di masyarakat. Sebagai contoh dalam Suku Sunda, anak dan cucu serta kerabat adalah aset untuk memberi dukungan kepada orang tua ketika memang memerlukannya. Sebagaimana yang disebutkan dalam salah satu pedoman hidup orang Sunda: "Ari munjung ulah-ka gunung, muja ulah ka nu bala; ari munjung kudu ka indung, muja mah kudu ka bapa" (yang harus disembah itu bukanlah gunung atau tempat-tempat angker, melainkan ibu dan ayah sendiri). Di situ tergambar bahwa penghargaan kepada orang tua dalam segala bentuk- 
nya merupakan nilai yang tinggi sebagai kewajiban kepada kelompok generasi yang lebih muda.

Kita juga dalam iklim modern dan demokratis tidak boleh lagi terjebak dalam pembagian tugas dan kerja yang bias gender. Hal ini berimplikasi bahwa tugas keperawatan lansia dalam keluarga merupakan tanggungjawab bersama, baik anak perempuan maupun anak lakilaki.

2. Merupakan tantangan tersendiri bagi pihak-pihak yang berkepentingan dan berkompeten untuk melakukan program. Paling tidak ada 3 bidang ilmu yang berkaitan langsung; medis-keperawatan, psikologi dan pekerja sosial. Jika dicatat ada beberapa fasilitas yang telah diberikan oleh pemerintah kepada penduduk lansia, yaitu KTP seumur hidup dan discount karcis sarana transportasi. Dan yang kedua ini lebih bagi lansia yang memiliki mobilitas tinggi dan tentunya masih banyak aktivitas yang dilakukannya.

Kedua, aspek ekonomi. Data yang ada menunjukkan bahwa jumlah lansia yang tercakup oleh sistem jaminan sosial hari tua seperti pensiun dan pesangon masih sedikit.
Pada tahun 1993 hanya 4,2 juta lansia yang memperoleh pensiun. Sehingga hanya sekitar 30 persen lansia yang ditanggung oleh sistem pensiun. Hal ini semakin menguatkan jaminan sosial dari keluarga merupakan sumber utama bagi lansia, khususnya yang bukan pensiunan pegawai negeri.

Ke depan perlu dirancang sistem jaminan sosial bagi lansia yang dapat menjadi support kehidupannya ketika sudah tidak produktif lagi dengan karakteristik penduduk kita yang sebagian besar bekerja pada sektor informal. Program seperti ini akan sangat bermanfaat bagi lansia pada keluarga tidak mampu di mana jaminan sosia dari keluarga tidak dapat terpnuhi.

\section{Kerangka Teori dan Pemikiran}

\section{a. Teori Transisi Demografi}

Transisi demografi berawal pada tingkat kematian yang tinggi, berangsurangsur beralih pada tingkat yang lebih rendah. Transisi demografi pada dasarnya dapat dibagi dalam tiga tahap :

\section{Tahap pertama :}

Angka kelahiran tinggi dan berada antara 40-50 perseribu setahun dan relatif stabil. Bersamaan dengan itu angka kematian juga tinggi dan berfluktuasi antara 30-50 per seribu 
setahun. Angka kematian yang tinggi ini disebabkan baik oleh bencana alam maupun akibat perbuatan manusia. Bencana alam dapat berupa bahaya kelaparan akibat kegagalan panen atau datangnya wabah dan bencana buatan manusia berupa peperangan atau kekacauan lain. Akibat angka kelahiran dan kematian yang tinggi, pertumbuhan penduduk yang merupakan selisih keduanya juga rendah.

\section{Tahap kedua :}

Tahap kedua transisi demografi adalah tahap pertumbuhan penduduk yang cepat, karena angka kematian turun dengan relatif cepat, sedang angka kelahiran turun dengan lam ban. Akibatnya terjadi kesenjangan antara angka kelahiran dan kematian yang besar dan terjadilah ledakan penduduk.

\section{Tahap ketiga :}

Pada tahap ketiga transisi demografi ditandai dengan angka kematian yang rendah di bawah 15 per seribu setahun dengan angka kelahiran yang rendah pula eli bawah 20 dan berfluktuasi dengan angka kelahiran yang rendah dan angka kematian yagn rendah pertumbuhan penduduk juga rendah. Pada dasarnya transisi demografi erat hubungannya dengan perkembangan ekonomi. Tahap pertama transisi terjadi dalam masyarakat agraris tradisional. Angka kelahiran tinggi secara alami tercermin dalam Total Fertility Rate di atas 10, sebagaimana dialami dalam masyarakat yang masih terbelakang pada masa ini. Angka tersebut stabil pada tingkat yang tinggi. Sebaliknya angka kematian berfluktualisi sesuai dengan kondisi ekonomi. Jika pertanian berhasil baik, makanan cukup angka kematian rendah dengan ca.tata.n tidak ada bencana lain. Sebaliknya kegagalan panen dapat berakibat fatal, dimana penduduk dalam waktu singkat menjadi separohnya.

\section{b. Teori Struktur Fungsionalisme}

Berdasarkan survei WHO yang dilakukan pada tahun 1980-an di beberapa negara Asia (Ogawa, 1989) ditemukan bahwa keluarga masih merupakan sumber pendapatan utama dibandingkan sumber lainnya bagi lansia, sebagai berikut:

\section{Tabel 2}

Proporsi Sumber Pendapatan yang

Diterima Lansia di Korea Selatan, Malaysia, Philipina, dan Thailand

\begin{tabular}{|c|c|c|c|c|}
\hline $\begin{array}{c}\text { Sumber } \\
\text { Pendapatan } \\
(\%)\end{array}$ & \multicolumn{5}{|c|}{ Negara } \\
\cline { 2 - 5 } & Korea Selatan & Malaysia & Philipina & Thailand \\
\hline Keluarga & 67 & 62 & 54 & 53 \\
\hline Bekerja & 19 & 19 & 22 & 28 \\
\hline Pensiun & 6 & 14 & 13 & 2 \\
\hline Lainnya & 8 & 5 & 11 & 17 \\
\hline Total & 100,0 & 100,0 & 100,0 & 100,0 \\
\hline
\end{tabular}

Sumber: Ogawa (1989) 
Masih dari Ogawa et al. (1994) berdasarkan penelitian yang dilakukan pada 798 lansia di Korea Selatan dan 3.252 lansia di Thailand, ditemukan hal-hal sebagai berikut: a) lansia dengan kesehatan relatif baik cenderung untuk tetap bekerja dibandingkan mereka yang sakitsakitan, b) dukungan ekonomi dan non ekonomi masih memainkan peran yang utama bagi lansia khususnya di kawasan Asia-Pasific. Temuan-temuan lainnya berkenaan dengan karakteristik demografis lansia yang berkaitan dengan aktivitas mereka di pasar kerja, yaitu: a) partisipasi lansia dalam kerja semakin menurun seiring dengan bertambahnya usia, b) lansia laki-laki menunjukkan tingkat partisipasi kerja yang lebih tinggi dibandingkan lansia perempuan, c) lansia dengan status kawin cenderung lebih aktif secara ekonomi, dan d) lansia dengan jumlah tanggungan (anak-anak) yang besar cenderung tetap aktif secara ekonomi.

Djohan (1996) berdasarkan penelitiannya tentang lansia di Jepang membagi lansia menjadi tiga kelompok berkaitan dengan pengaruhnya terhadap keluarga, yaitu: a) lansia produktif adalah mereka yang masih aktif bekerja penuh maupun paruh waktu dan merasa tidak tergantung pada anak-anaknya; bahkan mungkin saja anaknya yang tergantung pada mereka, b) lansia setengah produktif adalah mereka yang masih dapat melakukan suatu aktivitas, tetapi tidak berhubungan dengan mencari nafkah. Untuk kebutuhan sehari-hari, mereka hanya mengharapkan dari pensiun dan waktunya lebih banyak digunakan untuk kegiatan yang bersifat hobi, kesenangan pribadi, seperti: bertemu teman-teman, membuat sajak kuno Jepang, melukis, kursus bahasa asing, olahraga, dan juga kegiatan sosial, seperti: membantu lansia lainnya yang udzur, membantu mahasiswa asing, dan ikut festival, dan c) lansia tidak produktif adalah mereka yang sudah jompo dan udzur yang membutuhkan perhatian khusus dari keluarga dan bagi yang tidak punya sanak kerabat, sebagian besar tinggal di panti jompo (rojin home).

Teori Struktur Fungsional menganalisis bagaimana semua elemen di dalam masyarakat bekerja sama untuk menciptakan keadaan ekuilibrium. Mereka mengukur bagaimana setiap bagian dari masyarakat berfungsi untuk menjaga agar masyarakat berjalan dengan lancar. Bagaimana cara pandang ini mengatasi penuaan? Para Fungsionalis berpendapat bahwa setiap phase usia melakukan fungsi tertentu dalam masyarakat. Sebagian besar fokus dalam pendekatan ini adalah pada bagaimana lansia, sebagai 
suatu kelompok, mengatasi transisi peran ketika mereka memasuki tahap kehidupan menua. Bagaimana individu beradaptasi dengan peran, norma, dan harapan yang berbeda dari lansia, dan untuk mengubah kapasitas fisik dan mental mereka?

Fungsionalis menemukan bahwa orang-orang dengan sumber daya yang lebih baik yang tetap aktif dalam peran lain menyesuaikan diri lebih baik dengan usia tua (Crosnoe dan Elder 2002). Tiga teori sosial dalam perspektif fungsional dikembangkan untuk menjelaskan bagaimana orang yang lebih tua mungkin berurusan dengan pengalaman kehidupan di masa depan Teori gerontologis paling awal dalam perspektif fungsionalis adalah teori disengagement, yang menunjukkan bahwa menarik diri dari masyarakat dan hubungan sosial adalah bagian alami dari menjadi tua. Ada beberapa poin utama untuk teori ini. Pertama, karena semua orang mengharapkan untuk mati suatu hari, dan karena kita mengalami kemerosotan fisik dan mental ketika kita mendekati kematian, maka wajar untuk menarik diri dari relasi dengan individu dan masyarakat. Kedua, ketika lansia mengundurkan diri, mereka menerima lebih sedikit penguatan untuk menyesuaikan diri dengan norma-norma sosial. Oleh karena itu, penarikan diri menjadikan mereka terbebas dari tekanan untuk menyesuaikan diri. Terdapat perbedaan dalam proses penarikan diri di antara pria dan wanita. Karena pria fokus pada pekerjaan dan wanita fokus pada pernikahan dan keluarga, ketika mereka menarik diri mereka akan tidak bahagia dan tanpa arah sampai mereka mengadopsi peran untuk menggantikan peran yang biasa mereka yang kompatibel dengan keadaan yang tidak terlibat (Cumming dan Henry 1961).

Penarikan diri dari kehidupan sosial (Disengagement Theory) yang dikemukakan oleh Cumming dan Henry (1961), beranggapan bahwa lanjut usia perlu menemukan peran pengganti bagi mereka yang telah hilang, dibahas lagi dalam teori aktivitas. Menurut teori ini, tingkat aktivitas dan keterlibatan sosial adalah kunci untuk proses ini, dan kunci menuju kebahagiaan (Havinghurst 1961; Havinghurst, Neugarten, dan Tobin 1968; Neugarten 1964). Menurut teori ini, lansia semakin aktif dan terlibat dalam aktivitas, maka mereka semakin bahagia dia. Kritik terhadap teori ini menunjukkan bahwa akses ke peluang dan aktivitas sosial tidak tersedia secara merata bagi semua. Teori ini mengusulkan bahwa kegiatan adalah solusi untuk kesejahteraan para manula tanpa dapat menjelaskan bagaimana distribusi akses ke 152 
peluang dan kegiatan sosial ini mencerminkan masalah kekuasaan dan ketidakadilan yang lebih luas di masyarakat. Selain itu, tidak semua orang menemukan kepuasan di hadapan orang lain atau berpartisipasi dalam kegiatan. Reformulasi teori ini menunjukkan bahwa partisipasi dalam kegiatan informal, seperti hobi, adalah apa yang paling memengaruhi kepuasan hidup di kemudian hari (Lemon, Bengtson, dan Petersen 1972).

Menurut teori kontinuitas, lansia tidak secara drastis mengubah gaya hidup, perilaku, atau identitas mereka. Mereka membuat pilihan khusus untuk menjaga konsistensi dalam struktur dan keyakinan kepribadian internal, dan struktur eksternal (misalnya, berhubungan/berelasi), tetap aktif dan terlibat selama masa tua mereka. Fokus dari pendekatan ini adalah untuk menguji bagaimana upaya lansia mempertahankan keseimbangan dan stabilitas sosial dengan membuat keputusan di masa mendatang atas dasar peran sosial yang sudah dikembangkan (Atchley 1971; Atchley 1989). Salah satu kritik terhadap teori ini adalah penekanannya pada penciptaan model penuaan "normal", dan tidak sesuai bagi mereka yang menderita penyakit kronis seperti Alzheimer dan lain-lain.

\section{c. Konsep Interaksi Ekologi (ageing-in-place)}

Ada 2 (dua) tujuan dari konsep ageing-in-plaace; Pertama, dari perspektif lansia dan keluarga mereka, kebanyakan lansia, pada hakikatnya lebih suka tinggal di rumah mereka selama mungkin karena di tempat itulah mereka menjalani kehidupan, dan memungkinkan untuk mempertahankan identitas dan kenyamanan (Cutchin 2004). Pindah tempat tinggal menjadikan lansia kehilangan relasi sosial, perubahan dalam rutinitas sehari-hari dan gaya hidup, juga meninggalkan apa yang menjadi kebiasaan lansia dalam kehidupan mereka. Sebagai contoh, Clarity (2007) menemukan bahwa 26\% menolak untuk tinggal di Panti Jompo karena akan kehilangan kebebasan. Bahkan mungkin menjadikan mereka, merasa tertekan, depresi, kesepian, sulit beradaptasi, kecewa, dan tidak bahagia (Chappin \& Dobbs-Kepper 2001).

Kedua, dari perspektif pembuat kebijakan, perawatan lansia di Panti jauh lebih mahal daripada perawatan di rumah oleh keluarga di dalam masyarakat (Chappell et al. 2004; Kaye et al. 2009). Pengeluaran publik yang tinggi di Panti Jompo menjadikan perhatian mendesak pembuat kebijakan serta profesional untuk menyediakan pelayanan 
alternatif untuk lansia di komunitas mereka. Sehingga tidak mengherankan, banyak komunitas lansia telah mendukung kebijakan dengan konsep ageing-in-place, dan lansia tetap rumah, serta pelayanan lansia berbasis masyarakat yang mulai berkembang. Bagi banyak kalangan kebijakan tersebut memberikan opsi baru untuk mereka yang membutuhkan bantuan agar tetap independen di tempat mereka dan yang tidak ingin pindah menjadi penghuni Panti Jompo dalam jangka waktu yang lama. Dengan demikian, pembuat kebijakan dan publik samasama telah menjadi selaras dam sesuai dengan keinginan lansia dengan konsep age-in-place.

\section{Simpulan}

Berdasarkan gambaran di atas sudah selayaknya pemerintah serius menghadapi fenomena peningkatan umlah penduduk lanjut usia dengan banyak implikasi yang mengikutinya. Perawatan lansia yang selama ini menjadi tanggungjawab keluarga telah mengalami pergeseran seiring dengan pola keluarga inti yang menjadi tren masyarakat di wilayah perkotaan. Sebetulnya Undang Undang tentang Lansia sudah dibuat yaitu UU RI No.13 Th 1998 tentang Kesejahteraan Lansia. Langkah selanjutnya adalah menindaklanjutinya dengan peraturan-peraturan pelaksanaan yang jelas dan melindungi hak-hak penduduk lansia.

Pada bagian ini akan perlu dipastikan lagi bahwa wacana lansia aktif dan produktif serta mandiri dan berguna adalah solusi dari tantangan akan semakin meningkatnya usia harapan penduduk. Makna yang terkandung pada kata produktif tidak selalu dikonotasikan dengan kegiatan ekonomi saja tetapi juga kegiatan sosial kemasyarakatan lainnya termasuk di dalam kegiatan relaksasi dan yang membuat lansia tetap bahagia (di antaranya yaitu kegiatan keagamaan). Secara prinsip, lansia harus tetap memiliki nilai, harga diri dan tetep bermanfaat bagi masyarakat. Sebagaimana disebutkan dalam UU RI No. 13 Th 1998 pasal 5 dan 6 ayat 1 bahwa lanjut usia mempunyai hak dan kewajiban yang sama dalam kehidupan bermasyarakat, berbangsa dan bernegara.

Masyarakat harus menempatkan penduduk lansia seperti warga negara lainnya, tidak diskriminatif dalam memperoleh hak dan memiliki kewajiban sebagai warga negara untuk turut memberikan kontribusi dalam pembangunan. Sehingga aspek humanisme perlu dikedepankan. Kita harus melihat penduduk lansia dari berbagai aspek; latar belakang, kemampuan, keteladanan dan 
kearifan serta bersama dengan mereka ada keterbatasan sebagai manusia. Diharapkan ke depan akan semakin menyempit gap antar generasi, masyarakat tidak boleh mengartikulasi lansia dengan beban dan konservatif, alih-alih sebagai sumberdaya insani yang dapat turut berkontribusi pada keluarga dan masyarakat.

Bersamaan dengan itu perlu tetap disosialisasikan agar di dalam diri pribadi lansia sikap percaya diri dan kesiapan untuk beradaptasi dengan keadaan yang semakin berubah. Jaminan nilai sosial di masyarakat nampaknya masih menempatkan lansia sebagai panutan, akan tetapi jangan terlalu menuntut dan terkesan mudah menyerah kepada keadaan. Sehingga wacana lansia produktif, mandiri dan berguna menjadi kenyataan dan menjadikan posisi lansia sarat akan keteladanan, karifan dan bijaksana dengan segenap pengalaman yang telah dilalui.

\section{DAFTAR PUSTAKA}

BPS. 1999. Profil Penduduk Lanjut Usia 1997. Jakarta: Badan Pusat Statistik.

1997. Laporan Sosial Indonesia 1997. Jakarta: Badan Pusat Statistik.
- 2015. Proyeksi Penduduk Indonesia 2010-2035. Jakarta: Badan Pusat Statistik. . 2018. Statistik Penduduk Lanjut Usia 2017. Jakarta: Badan Pusat Statistik.

Djohan, Eniarti. 1996. "Lansia di Jepang: Aspek Demografis dan Sosiologis". Buletin Pengkajian Masalah Kependudukan, VII (1 \& 2), pp. 63-81 Jakarta: LIPI.

Garna, Judistira K. 1996. Sistem Budaya Indonesia. Program Pascasarjana Unpad Bandung.

Iecovich, Esther. 2014. Aging in place: From theory to practice. Anthropological Notebooks 20 (1): 21-33. ISSN 1408-032X () Slovene Anthropological Society.

https://pdfs.semanticscholar.org /f9fc/8e6e859408543cb512a49 9d37a4267edb348.pdf

Infodatin Kemenkes RI. 2016. Situasi Lanjut Usia (Lansia) di Indonesia. ISSN: 2442-7659

Kantor Menteri Negara Kependudukan/BKKBN. 1998. Data dan Informasi Penduduk Lansia Indonesia.

Novak, Mark. 1997. Aging \& Society; A Canadian Perspective. Ontario: ITP Nelson. 
Ogawa, Naohiro. 1989. "Population Change and Welfare of the Aged". Nupri Reprint Series No. 32/1989, pp. 105-132.

Ogawa, Naohiro, et al. 1994. "Health Status of the Elderly and Their Labour Force Participation in the Developing Countries along the AsiaPasific Rim". Nupri Reprint Series No. 51/1994, pp. 348373.

Rosidi, Ajip. 1984. "Ciri-ciri Manusia Dan Kebudayaan Sunda". Masyarakat Sunda dan Kebudayaannya, Edi Suhardi Ekadjati, (ed), hal. 125-161. Jakarta: Girimukti Pasaka.

Suryadi. 2017. Aktivitas Lansia (Kasus Pada Suku Sunda Di Kelurahan Sekeloa Kecamatan Coblong Kota Bandung). Ponorogo: Wade Group.

Tjiptoherijanto, Prijono. 1990.

Transisi Demografi dan Pembangunan Di Indonesia. Disampaikan dalam Forum Geografi Nomor 06. http://journals.ums.ac.id/index.p $\mathrm{hp} / \mathrm{fg} /$ article/download/4856/32 45

Wirakartakusumah, M. D. 1998. "Household Structure and the Elderly in Indonesia", Asian Population Studies Series No. 152. 